DOI: $10.19195 / 2353-8546.6 .9$

\author{
SANJA LAZAREVIĆ RADAK \\ Serbian Academy of Science and Arts (Belgrade, Serbia)
}

\title{
War Trauma and the Terror of Freedom: Yugoslav Black Wave and the Critics of Dictatorship
}

\begin{abstract}
War Trauma and the Terror of Freedom: Yugoslav Black Wave and the Critics of Dictatorship. Relying on the concept of cultural trauma, the author interprets the attitude of post-Yugoslav societies towards the so-called Black Wave films. The paper examines the prohibitions of these films during the communist period, the increased interest in them during the 1990s, and finally, its disappearance from popular culture, which all testify the multilayered cultural trauma which Yugoslav and post-Yugoslav societies have been going through since the 1940s.
\end{abstract}

Keywords: cultural trauma, political myth, Black Wave, communism, disintegration of Yugoslavia

Травма войны и проблема свободы: югославские фильмы и критика диктатуры. Опираясь на концепцию культурной травмы, автор интерпретирует отношение постюгославских обществ к фильмунуар. В коммунистическую эпоху Новые фильмы были запрещены; в девяностые годы возник некоторый интерес к «черным фильмам», наконец, они исчезли из популярной культуры. Это свидетельствует о многослойности культурной травмы через которую прошли югославские и постюгославские общества начиная с 1940-х годов до настоящего времени.

Ключевые слова: культурная травма, черный фильм, югославские, пост-югославского общества, коммунизм, распад Югославии

* Address: Institute for Balkan Studies, Serbian Academy of Science and Arts, Knez-Mihailova 35/4, Belgrade, Serbia. E-mail: sanjalazarevic7@gmail.com. 


\section{Historical and Theoretical Framework}

This paper explores the relationship between collective trauma as public narrative and its impact on the reception of the film as a product of popular culture. Historical and cultural trauma operates as a concept represented in stories, great narratives, political myth, socially endorse memory and an internal logic linking history to the present state. Mohat, Thompson, Thai and Tebes, conceptualize trauma as a public narrative in order to simplify theoretical model that specifies how historical trauma as a public narrative influences community ${ }^{1}$. They argue that trauma functions as a public narrative for particular communities that connect present-day experience to the trauma. History is, in part, collective memory and like memory is a reconstructive process. Trauma narratives represent an interplay between personal stories and culture, and are cultural constructions of trauma. A narrative conceptualization does not deny the veracity of past events but redirects focus on how those events are represented and linked to outcomes today. Hence, trauma consists of public narratives that link traumatic events in the historic past to the contemporary local contexts so that trauma becomes part of the cultural narrative. Through shaping narratives, society express individual and collective identity ${ }^{2}$. I belive that great narrative about the divided Balkans exposed to consequences of "ancient hatreds" is a clear example of a narrative that enable continuous transfer of trauma. Repeatable conflicts which are the key to this narrative became reality which affects group consciousness, mark and change post-Yugoslav societies in fundamental ways, resulting in change/loss of lifestyle and values. This great narrative or political myth is present in literature, pseudo-science, political discourse, but at the same time it occupies a large space in popular culture. The film is its most prominent transferor and critic.

\section{Political myth on Balkan Peninsula}

Yugoslav and post-Yugoslav societies establish their identity around the great narrative of the ethnic and confessional variegated Balkan peninsula, situated between, or above Orient and the Occident. According to this narrative or political myth which I understand as a prototype on unquestionable secular story about the comunity, its origin and the relationships in it, the specific position of the Balkan peninsula conditions, perpetuous mutual conflicts and a desire of the Others (usually, the "West") to conquer and assimilate people of the Balkans ${ }^{3}$. Social theorists (Flood)

${ }^{1}$ N.V. Mohatt et al., "Historical trauma as public narrative: a conceptual review of how history impacts present-day health”, Soc SCI Med 106, April 31 2014, pp. 128-135.

2 Ibid., p. 135.

3 G. Đerić, Prvo lice množine, Beograd 2005, p. 78; I. Čolović, Politika simbola, Beograd 2000, p. 123; S. Lazarević Radak, Na granicama Orijenta: predstave o Srbiji u engleskim i američkim putopisima između dva svetska rata, Pančevo 2011, p. 225; V. Velmar Janković, Pogled s Kalemegdana, Beograd 
characterize myths as stories that possess the status of sacred truth within one or more social groups. Myth becomes an ideologically marked narrative that purports to give a true account of a set of past, present or political future widely accepted as valid in its essentials. ${ }^{4}$ It creates the codes of collective identity, unifies the beliefs of social groups and legitimates the political and social institutions. Acctualy, it is a narrative that must be accepted as true, although its veracity is not the central issue. One of the difficulties with political myth is the terminology, considering "myth" is a term that has such a clear definition as a fictive story which gives cognitive, ontological and moral explanation while using imagined characters and events. Secular myth is fluid, without clear boundaries and full of contradictory meaning, although it is not an obstacle for creating a specific logic or mythic discourse. This logic is the reason why political myth does not contain anything of the unexpected or arbitrary. The mechanisms of the collective imagination are related to a limited number of patterns ${ }^{5}$. Thus, the myth is understandable and acceptable to a large number of people. Although some political myths gives the impression of rational, the Balkan myth operates with sacral elements relying on the idea that the peninsula is "cursed" or "choosen" to be "above" and/or "beyond" other parts of European continent and European people. Milan Matić believes that political myth is a story that gives the evocation on the past and projection for the future with the intention to provide arguments for present situation and this is exactly what Balkan myth does ${ }^{6}$. For example, according to this myth: 1 . Ancient hatreds have their roots in geographical position of Balkan peninsula; People from the Balkans were always in war; each new war demands revenge; Balkan is cauldron of Europe, powder keg, etc. In this context, sacral elements are added to evoke emotions. 2. The geographical position, mutual hatreds, the need for revenge gives explanation for wars, revolutions, lack of economic and social stability. In the present, the Balkan myth gives an explanation and justification of events. 3. Wars will be repeated, so one cannot expect a radical political change in the future. Each Balkan state has its own version of the myth in order to maintain the position of the greatest hero and martyr.

According to Miodrag Popović, this narrative is present in medieval writings ecclesiastical and secular, prose and lyrical and inspired by history and legends ${ }^{7}$. The society relies on myth, while the individual, as a cultural subject, interiorizes its content and observes the world according to it ${ }^{8}$. One learns the elements of this narrative to the extent that its destabilization acts as a threat to the entire value system. Imaginative

1938. In literature: I. Andrić, Na drini ćuprija, Beograd 1945. In public discourse: V.N. Velimirović, Legends and stories; Teodosije, Žitije sv. Save, etc.

${ }^{4}$ C. Flood, Political Myth: A Theoretical Introduction, New York-London 2001, p. 172.

${ }^{5}$ K. Milošević, M. Stojadinović, "Understanding the contemporary political myth through the prism of national identity", Facta Universitatis 2012, Niš vol. 11, pp. 77-87.

${ }^{6}$ M. Matić, Mit i politika, Beograd 1998, p. 106.

7 M. Popović, Vidovdan i časni krst, Beograd 2007, pp. 17-18.

${ }^{8}$ M. Matić, op. cit., p. 19. 
remembering is entangled in stories and narratives that society is repeating, often in compulsive manner, but these stories are permanently only partially unfolded ${ }^{9}$. One is entangled in a plurality of stories in both directions of past and future, and neither past nor future is ever brought to the point of full closure. This process enables re-writing and re-opening the great narratives in order to correct them and harmonize it with present.

After the Second World War, in order to preserve social stability, the Communist Party tried to reshape this narrative, introducing the discourse of class struggle and the importance of the Revolution. The previous divisions became a part of silent discourse. Any discussion or dialogue about "divisions and ancient hatreds of the Balkans" withdraws sanctions. The absence of constructive dialogue represses trauma and intensifies tension. Hence, once seen as a danger, the cultural and national diversity became a platform for so called "brotherhood and unity of all nations and nationalities." Like other forms of art, film uses the critical language which reveals "the unspeakable", questioning brotherhood, unity, mutual understanding and the values of the Revolution in order to provoke the dominant political discourse. Pointing out tensions and thematizations of social, ethnic, class and confessional divisions serves to provoke the authoritarian rule. Accidentally, more than thirty years later, the Black Wave film era becomes one of the most provoking explanations of the disintegration of Yugoslavia and national/confessional/ideological tensions that preceded the war. The years of suppression, the fact that they were banned without administrative ban while their authors were stigmatized as anarchists or enemies of socialism, sparked curiosity. Public was wondering what was hidden from them for decades. These films have dealt with all the sensitive issues that the Communist Party covered up. One of them was question of so called "brotherhood and unity".

Due to the complexity of this question this essay argues on different theoretical levels. I will start from the history of the Black Wave offering the interpretation of the interplay between a set of mythical narratives connected to the "historical experiences" and their representations in the Black Wave. Recent cultural studies have exploited the concept of trauma to adopt it to the explanation of sudden, unexpected outbursts of collective violence. According to Daniel Šuber and Mirosav Hadžić, Communist leaders and the various institutions systematically exploit the prevention of catharsis and the suppression of traumas for the sake of stability preservation. The national project had to settle an explosive set of tensions between the various ethnic groups inherited form the Second World War relying on the rethoric and myth about everlasting brotherhood, unity, national diversity and mutual respect ${ }^{10}$. The notion of collective trauma reckons with the observation that traumatic events can be suppresed by means of political repression as that fostered by the Titoist regime ${ }^{11}$.

9 J. Butler, The Psychic Life of Power: Theories in Subjection, Stanford 1997.

10 D. Šuber, "Myth, collective trauma and war in Serbia: a cultural-hermeneutical appraisal", Anthropology Matters 2006, vol. 8, no. 1, pp. 3-18.

11 Ibid., p. 14. 


\section{The Black Wave: screening trauma}

During the sixties young Yugoslav filmmakers were inspired by French, Polish and Czech New Wave films, new social movements and Student protest in Europe. Polish films, especially works of Andrzej Wajda as an independant leader of new spirit in Polish cinema inspired Yugoslav filmmakers. Film Ashes and Diamonds (Wajda, 1958) encouraged filming Zaseda (The Ambush, Živojin Pavlović, 1969). Both Wajda and Pavlović are telling the stories about the last days of World War II and first days of freedom through personal drama of the protagonist. Polish films were regarded a testament of the struggle for personal and national freedom and thus, cinema role model. The so-called Yugoslav Black Wave also drew its ideas from influential film movements such as Surrealism, Italian Neorealism and the French New Wave as well as the Montage theories of early Soviet filmmakers such as Sergei Eisenstein. Opposing to real socialism was achieved by pointing out cracks in the idealized image of the socialist system while drawing attention to unemployment, juvenile delinquency, prostitution, economic poverty, marginalization of ethnic groups, along with the first thematizations of homosexuality and drug abuse. Most of all, the Black Wave films tried to re-open the theme of conflicts in the Second World War, as much as ideological, political, economic and social problems that followed after it. On the charge that their work had a subversive potential, some of the best directors left the country (Dušan Makavejev, Jovan Jovanović), others have been arrested (Lazar Stojanović) or under the constant police surveillance, or their work was banned. In chronological frames of ten years, the authors developed a specific film language which was unique - different from previous and the one that followed. Some of the most prominent directors of the Black Wave were: Dušan Makavejev (W.R. Mysterises of Organism, 1971), Želimir Žilnik (Rani radovi, Early works, 1969), Lazar Stojanović (Plastični Isus, Plastic Jesus, 1971), Živojin Pavlović (Zaseda, The Ambush, 1969), Aleksandar Petrović, Puriša Đorđević (Devojka, A Girl, 1965, San, Dream, 1966, Jutro, Morning, 1967, Podne, Noon, 1968), Mića Popović (Delije, 1968).

During the late 1980s, just before the break of Yugoslavia, ethnic and economic tensions were visible more than ever. Some of these films became popular during the $1960 \mathrm{~s}$ thanks to their participation and recognition in European festivals, but most of the Black Wave films were publicly released in Yugoslavia in 1980s. Unfortunately, delayed screening brought misinterpretations, revealing the new consequences of repression.

\section{Division and Trauma}

During the Second World War future Yugoslav republics were divided into supporters of the official Royal Army and the Communist army (partisans) led by the future winner, Josip Broz Tito. When the war was over, this division brought 
about countless conflicts and the suffering of the population. Soon, the memory of it was removed from the public discourse. The Black Wave makes these division visible while becoming a visual testimony and artistic expression of conflicts and suffering. The "national", "ideological" and "political" topics were usually ignored and the Communist Party banned the films which deconstruct and reconstruct the resulting problems. This was the first ideological theme which was suppressed in order to become visible through the following decades. Black Wave thematises these problems in the movies: Delije (Mića Popović, 1968), The Man from the Oakwood (Čovek iz hrastove šume, Mića Popović, 1964). The Morning (Jutro, Puriša Đorđević, 1964), The Ambush (Zaseda, Živojin Pavlović, 1969) ${ }^{12}$. Their central narratives follow the various aspects of freedom which is represented as a fraud. The Communist Party offered the reasons for prohibition of these films: "perverse dialogues", "insults against the Communist Party", "lies on partisans", "anarchist provocation", "subversive and decadent ideas". The Communist Party denied all that could jeopardize its ideal image of freedom and consistently applied Marxism ${ }^{13}$. Nevertheless, the Black Wave represents liberation as a time of porous hierarchy, the time when "people" expresses itself becoming a leading figure which erased "the old world" and the "old rules and values" to create a new society based on new values. The groutesque images of intemperance, greed, aggression, traumatized individuals who wander aimlessly, enter into force when "crowd comes to power"14. Their traumas consist of flashback, halucinations, nightmares, alcoholism, phobias, anxiety attacks, auto-destructive behaviour, depression and at last suicide. For example, depressive protagonists from the film Delije are drunk, agressive and at the end of the film the only solution left is suicide. Ivo Medanić Vrana from The Ambush is anxious, dissapointed, depressive, while the victim from The Morning is suffering from insomnia while wondering who will kill her at the end.

\section{Ideological divisions: Expelling Stalin from Yugoslavia}

In the late 1940s the Yugoslav president Josip Broz Tito opposed Stalin. Few people could imagine that this will be the ground for the emergence of new trauma. More than two hundred thousand people who were Stalin's supporters or were linked with Stalin's line, escaped from Yugoslavia to Bulgaria or Romania. This initiated another division in Yugoslav society. This division became a ground for new trauma. Those who were alleged supporters, accused to be stalinist for another reasons (supporters of liberal capitalism, accusations of memebership in the secret association in Yugoslav Democratic Youth, homosexuality, private issues for revenge and ap-

\footnotetext{
12 N. Stojanović, “Celuloidni svemir", YU film danas 2012, no. 102/103, p. 110.

13 B. Tirnanić, Crni talas, Beograd 2008, p. 58.

14 M. Ristivojević, “Bahtin o karnevalu”, Etnoantropološki problemi 2009, no. 4(3), pp. 197-210.
} 
propriation of property) settled in United Kingdom or the United States in mid-July 1949. The Yugoslav authorities opened the camp where they imprisoned supporters or alleged supporters of the former policy of Informbiro in order to "rehabilitate" them using psychical and physical violence, forcing them to admit their political and ideological error. After the liberation from some of the infamous camps (Goli otok, also called Naked Island or Yugoslav Gulag), the former prisoners had difficulty to integrate socially. The Black Wave reveals ambivalent attitude towards Tito's politics, pointing out the fact that Goli otok and mass migrations were a possibilty to get rid of opponents and political competition. The population was living in the fear of false accusations, camps, torture and re-experiencing Second World War. Many prisoners were not Stalin supporters which is indicated in the Black Wave films (Miroslav Antić, Holy Sand). Tito was represented as Stalin of the Balkans, a new communist leader which political position was rooted in the rhetoric of peace in the world, anti-imperialism, and good relations with both parts of the polarized world. Later on this will result in the foundation of Non-alligned movement while Party was using the elements of rewritten Balkan myth.

The first banned film Holy Sand (Sveti pesak, Miroslav Antić, 1968), thematizes the life of a former partisan and political brigade comissar, Aleksandar Vinski who has spent a couple of years in such a camp not knowing what was his fault. All he knew about his fault is that "he offended the society". Twenty years after the war he comes to visit the old monument erected in the honour of his dead comrades, unwanted and abandoned. They were roll-calling the dead and alive, but not Aleksandar Vinski. As he stood before his dead comrades, he realizes that he had never existed. At the end of the film, he is dying alone, in the sand, blaming himself for crimes he did not admit. He is not a man, but a doll crucified on the banks of the Danube. Velimir Bamberg, the protagonist of the film The Rats Woke Up (Buđenje pacova, Zivojin Pavlović, 1967) passes through the similar drama of alienation regarding the fact he is abandoned and rejected from the rest of society. His whole life becomes a story on traumatized person. Alluding to those who live in the sewers and eat garbage, Pavlović thematises life of alleged former Stalin sympathizer, who is wandering in an effort to come up with his own life. Monitored, checked, haunted by the possibility that anyone can accuse him of being an enemy, create an atmosphere of a new war.

\section{Betrayed revolution and historic trauma}

The Black Wave was developing at the time of student demonstrations which affected the whole Europe. In Yugoslav capital, Belgrade, young people were demanding a return to the promised time of ideal socialism, usually confusing it with the ideas of the hippie movement Plastic Jesus (Plastični Isus, Lazar Stojanović, 1971. Želimir Žilnik, Rani radovi (Early Works, 1969). WR Mysteries of Organism (Misterije 
Organizma, Dušan Makavejev, 1971) ${ }^{15}$. The student revolution was just a symptom of desire to have better social conditions, employment opportunities, increasing of social standards.

Simultaneously, the Black Wave was depicting the depressed and angry young people who aspire to the capitalist model of life - changing cars, clothes, partners, using drugs, stealing, or an opposite side in which marginal subjects live: unemployment, a hard life, domestic violence, the inability to cope in the world that officially opt for socialism, but in practice implements what is its opposition (Mlad $i$ zdrav kao ruža, Young and healthy as a rose, Jovan Jovanović, 1971). Jovanović tells a story about a young deliquent Stevan Nikolić - "Steve" who becomes a mafia boss of Belgrade. With foresight of things to come, during the 1990s, Jovanovićs protagonist says: "I am your future". This is a story about crime, drugs and the future of Serbia. Parents of "Steve's" generation were revolutionaries but their revolution was betrayed. Young people could see only the dark side of revolution. Through these images they point out a huge class divisions in socialist society. The children of the Communist Party functionaries live the capitalist, "Western lifestyle", while others remain on the margins of society (Restless, Nemirni, Kokan Rakonjac, 1967). It reveals a trauma of people who hoped for a better life in freedom. But political elites and the margin cannot switch the place. One night, after the road accident the eyewitnesses were claiming that they saw a woman behind the steering wheel. It was actually the four teenagers who were driving around for fun, but the girl who was with them left the car in the middle of the highway. The boys have been chased by the police and they have crashed fatally. The fourth person is a young woman, a daughter of a communist Party functioner. Her family position, relationships and her "red - bourgoise charm" are protecting her from guilt. She meets a poor girl from the vilage who is searching for a job in Belgrade. A young daughter skillfully managed to replace personal documents and identity with a hungry vilage girl and escape the law. Instead of brotherhood, unity, equality, solidarity, justice, a new class divisions arise. Criminal becomes the means used by former revolutionaries, Communist Party officials and their children.

In public, Second World War was interpreted as a revolution which brings a better life, but only a communist elite got benefits. This was one of the major disappointments of peasants and working class - the largest part of population who fought in the war, but instead of receiving recognition, their lives were taking place in the margin.

A third subgroup of films on freedom was using a nationalist scenario to show the possibility of the breakup of Yugoslavia. Suggested reasons are: unresolved conflicts during the post-war phase and betrayal of socialist ideals, or implicit/explicit nationalism. Such films are Želimir Žilnik's Early works (Rani radovi, 1969) and

15 P. Volk, "Dušan Makavejev i protest do zadovoljstva”, Izraz: časopis za književnu i umjetničku kritiku, Zagreb 1984 (Izraz : časopis za književnu i umjetničku kritiku, 13, knj. 25, br. Maj-juni 5/6, 47749az: časopis2.). 
Lazar Stojanovićs film Plastic Jessus. While the first film depicts the rape and burning of a girl named Yugoslavia, in the second film the author uses archival material from the Second World War to display the scenes from the concentration camps in which members of one "Yugoslav nationality" were killing members of another nationality. While his protagonist, Tomislav Gotovac is speeding on a motorcycle in order to reach the better future, the rearview mirror reflects the past. Rearview mirror becomes a surface on which one can read the text on social trauma. One can see victims of the Second World War, concentration camps, paramillitary, destruction, bombing, chetniks, ustashe, massacred bodies and presence in which communist officials are enjoying carnivalesque ecstasy. He anticipates the future of socialist Yugoslavia. The author, a promising director, Lazar Stojanović, spent three years in prison, and he was tried for insulting the personality and ideas of President Josip Broz Tito.

Finally, the Black Wave makes visible a double margin ${ }^{16}$, which was masked with the help of rhetoric on social security. No matter how heterogeneous, these subaltern subjects ${ }^{17}$ compose a critical aesthetic unity which testifies to the imperfections of real socialism. Their space/place remains connected to all other parts of society, enabling the inversion of the city and becoming a mirror of objectivity. In an environment dominated by mud, humid houses and poverty, the narrative of hopelessness, and inability to overcome the economic misery becomes the central one. Paradigmatic film is When I'm Dead and Gone (Kad budem mrtav i beo, Živojin Pavlović, 1967 $)^{18}$. The protagonist Janko Bugarski is a petty criminal, seasonal worker, vagabond and aspiring singer who wants to make a big career. He is destined to failure and an absurd, premature, violent death. The second group includes films that thematize the marginalization of Romani (I Even Met Happy Gypsies, Skupljači perja, Aleksandar Petrović, 1967). Beli Bora (White Bora) falls in love with young Tissa who is arranged to get married to another man. Tissa tries to escape, but a couple of drivers rape her. She must return to her tribe and misery. On the other side, while defending his honour, Bora kills his opponent. He must leave the tribe. The aesthetics of the film remain the aesthetics of misery reinforced by the image of Romani, their houses, resorts, inns, clothing, fights, and in general, the consequences of living in poor social conditions.

16 People on the margin in a society or a country which is marginal in world economy and politics.

17 A term originaly introduced by Antonio Gramsi, developed by Gayatri Chakravorty Spivak, relying on Joanne Sharp. Subaltern subjects are people who have been silenced in the administration of the state they constitute. The reasons can be colonialism, class statification, marginalization on ethnic, gender, sexual criteria.

18 R. Munitić, Te slatke filmske laže, Beograd 1977, p. 177. 


\section{From film to reality: the end of Yugoslavia and revival of the myth}

Twenty-five years later followed the disintegration of the Socialist Federative Republic of Yugoslavia. In order to explain this process, people of Yugoslavia mobilized pseudo-scientific, characterological, anthropo-geographical and ethnographic manuals of the early twentieth century. Yugoslavia was singularized and anthrophormized as the "one who must take the blame". It was labeled as "the East", "Oriental", "Bureaucratic", "Communist", "something imposed on the people who lived there"19.

Along with this, nationalist thematisations of the distant past of the nation created pseudoscience about the nature of national identity, appropriation and mutual celebration of national greatness ${ }^{20}$. The motifs of heroism and tragedy, myths about blood and soil, justification of the mutual hatreds, vendettas, were explained as a part of ancient history, something which dates back to the Middle Ages, or even earlier. It strengthened the identity and the formation of autonomous communities ${ }^{21}$. The consequences of confusing politics and narratives exposed their dangerous side. The rethoric about the country become more religious than secular and created "eternal state", "Serbian", "Croatian", or "other soil that requires sacrifice for the country"22. The war of independence from socialist Yugoslavia was represented as a continuation of Second World War which Black Wave anticipated. They became part of extended version on Balkan myth suppresed during the Communist period. So, the trauma was not healed, but supressed. Societies pass through some sort of post-traumatic stress syndrome. The events of the past are strong enough to perpetrate suffering that society respond on emotional reaction. The first and most visible is agression.

In this historical context, some of the the Black Wave films were shown in the public for the first time. At first, their content was used as the evidence of repression, dictatorship, the absense of freedom of expression under Tito's communist state. This way, the polemical and critical film was used for the purpose of one in a series of political manipulations which reflects the ambivalence towards the past and the inability of post-Yugoslav societies to achieve historiographical consensus.

Several years after the war in ex-Yugoslav republics had begun, the interest in the Black Wave ceased. The trauma was not healed, but the aggresion enabled valve. During the war, new films continued creating associations between the process of disintegration of Yugoslavia and the Second World War. The paradigmatic films are: Underground (Podzemlje, Bila jednom jedna zemlja, Emir Kusturica, 1995); The Knife (Nož, Miroslav Lekic, 1999, based on the novel by Vuk Draskovic) and Pretty Village,

${ }^{19}$ M. Radojević, "Jugoslovenska ideja kao deo jugoslovenskog kulturnog nasleđa”, [in:] Ogledi i jugoslovenskom kulturnom nasleđu: okviri konstruisanja jugoslovenskog kulturnog nasleđa, Beograd 2012, pp. 21-37.

${ }_{20}$ More in works: I. Čolović, Politika simbola, Beograd 2000; M. Živković, Srpski sanovnik, Beograd 2011; G. Đerić, Prvo lice množine, Beograd 2005.

21 M. Matić, op. cit., p. 314.

22 J. Mirić, Demokracija u postkomunističkim društvima, Zagreb 1996, p. 225. 
Pretty Flame (Lepa sela lepo gore, Srdjan Dragojevic, 1996). The forty-five year long period between the nineties and the year 1945 disappeared in a historical vacuum, so the films from late 80 s and mid 90 s have a continuum with those form a previous decades.

\section{Bibliography}

Butler, J. 1997. The Psychic Life of Power: Theories in Subjection. Stanford: Stanford University Press. Čolović, I. 2000. Politika simbola. Beograd: XX vek.

Đerić, G. 2005. Prvo lice množine. Institut za filozofiju i društvenu teoriju. I.P. Beograd: Filip Višnjić. Flood, C. 2001. Political Myth: A Theoretical Introduction, New York-London: Routledge.

Lazarević, R.S. 2011. Na granicama Orijenta. Pančevo: Mali Nemo.

Matić, M. 1998. Mit i politika. Beograd: Politeia.

Milošević, K., Stojadinović, M. 2012. "Understanding the contemporary political myth through the prism of national identity." Facta Universitatis 11. no. 1. 77-87.

Mirić, J. 1996. Demokracija u postkomunističkim društvima. Zagreb: Prosvjeta.

Mohatt N.V. et al., 2014. "Historical trauma as public narrative: a conceptual review of ho history impacts present-day health.” Soc SCI Med 106. April 31. 128-136.

Munitić, R. 1977. Te slatke filmske laže. Beograd: Filmski centar Srbije.

Popović, M. 2007. Vidovdan i časni krst. Beograd: XX vek.

Radojević, M. 2012. "Jugoslovenska ideja kao deo jugoslovenskog kulturnog nasleđa." In Ogledi i jugoslovenskom kulturnom nasleđu: okviri konstruisanja jugoslovenskog kulturnog nasleđa. Beograd: Odeljenje za etnologiju i antropologiju Filozofskog fakulteta Univerziteta u Beogradu.

Ristivojević, M. 2009. "Bahtin o karnevalu." Etnoantropološki problemi. no. 4(3). 197-210.

Sotero, M.M. 2006. "A Conceptual Model of Historical Trauma: Implications for Public Health Practice and Research." Journal of Health Disparities Research and Practice, vol. 1, no. 3. 93-107.

Stojanović, N. 2012. "Celuloidni svemir". YU Film Danas. no. 102/103. Beograd: Arts and Artists.

Šuber, D. 2006. "Myth, collective trauma and war in Serbia: a cultural-hermeneutical appraisal." Anthropology Matters 8. no. 1.3-18.

Tirnanić, B. 2008. Crni talas. Beograd: Filmski savez Srbije.

Volk, P. 1969. “Dušan Makavejev i protest do zadovoljstva.” Izraz: časopis za književnu i umjetničku kritiku 13. knj. 25. br. Maj-juni 5/6. 477-492.

Živković, M. 2011. Srpski sanovnik. Beograd: XX vek.

Przyjęto do druku/Accepted for publication: 5.03.2017

Miscellanea Posttotalitariana Wratislaviensia 6/2017

(C) for this edition by CNS 